\title{
Stakeholder collaboration to support accountability in village fund management and rural development
}

\author{
Fannidya Hamdani Zeho, Ardian Prabowo, Roro Ayu Estiningtyas, Mahadiansar", and I Gede Eko \\ Putra Sri Sentanu \\ University of Brawijaya, Malang, Indonesia \\ *Correspondence email: mahadiansar@student.ub.ac.id
}

\section{ARTICLE INFO}

\section{Research Article}

Article History

Received 2 June 2020

Accepted 4 July 2020

Published 31 October 2020

\section{Keywords}

accountability;

collaboration; finance;

stakeholder; village fund

JEL Classification

$\mathrm{H} 72 ; \mathrm{H} 83 ; \mathrm{O} 2 \mathrm{O}$

\begin{abstract}
The village government has an substantial responsibility in managing human resources to produce regional economic benefits. This research aims to identify the stakeholder collaboration to support accountability in village fund management and rural development. This study used an interactive approach with data collection methods such as structured interviews, documentation, and observation. The object of the study is village officials in Pranggang Village, Plosoklaten District, Kediri Regency, East Java Province. The results of the study showed that the village government has not optimally carried out its role in involving more stakeholders. Collaborative stakeholders in managing village funds involved village government officials, activity management team and community. They play a positive role in bringing about village accountability in managing village funds. An increased community participation contribute to program evaluation activities and effectiveness in the village financial management. The accountability of the village funds utilization has met the Home Affairs Ministerial Regulation number 113 of 2014. In addition, social accountability has been applied in various forms of effective interactions between the community and village government. Much efforts are required to improve the quality of human resources through more stakeholder engagement, training activity and community empowerment.
\end{abstract}

Citation: Zeho, F. H., Prabowo, A., Estiningtyas, R. A., Mahadiansar, \& Sentanu, I. G. E. P. S. (2020). Stakeholder collaboration to support accountability in village fund management and rural development. Journal of Socioeconomics and Development, 3(2), 89-100. https://doi.org/10.31328/jsed.v3i2.1395

\section{INTRODUCTION}

The direction of the National Long-Term Development Plan (RPJPN) 2005-2025 states that one perspective of the long-term development for the region can be associated with the success of development at the rural level, especially by synergizing between urban and rural activities in the sustainable regional development.

The legal basis of the village development is reinforced with Law number 6 of 2014 concerning villages. This regulation contains a vision that the government is focusing on the developing and strengthening village governance. Law number 6 of 2014 provides the basis for policies aimed at encouraging initiatives, movements and participation of village communities to develop its potentials and assets for mutual prosperity and to form a professional, efficient, effective, open, and accountable village government. 
The leadership of the central government carried out by the new order regime was the forerunner to the implementation of a government system that did not provide opportunities for regional growth and local capacity development (Setiawan et al., 2018). Thus, the regulation of the village gives hope for the formation of a good village government (good governance) and provides services for increasing economic activity in the village. The village government also needs to be prepared so that it can carry out its tasks by implementing accountability.

Accountability is a vital element of good governance and refers to the accountability of government officials for their activities in public management (Drake \& Dingler, 2001). One form of excellent services that must be carried out by the village government is accountability following the mandate of the regulation. According to Scott (2003), accountability is a mechanism that must be carried out by public officials to explain and ensure that their actions are appropriate, ethical, and responsible. The accountability creates mechanisms that hinders or minimizes the misuse of authority and corrupt behavior in the village (Bovens et al., 2008; Drake \& Dingler, 2001; Rizkita, 2016)

Rahmaddhana \& Sentanu (2020) revealed that local government management still possesses potential problems related to the efficiency of budget planning, abuse of authority and corruption, and performance accountability. Other problems are policies that are a disincentive to investment, decision-making authority, and unresponsiveness in public services.

Implementation of rural development often creates a divergence between the goals and priorities of development (Sisto et al., 2018). Village economic development is how to meet the needs of the community for welfare purposes, but the process of village government accountability also meets the requirements of the central government. At present, the average village development budget is two to three billion per fiscal year (Solikhah \& Yulianto, 2018). According to the Minister of Domestic Affairs Regulation 113 of 2014 concerning Village Finances, the source of the village development budget comes from village own revenue (PADes), transfers fund (funds for village, village fund allocation, etc.) and other revenue.

According to Rizkita (2016), there are three types of village government accountability. First is fiscal accountability. Fiscal accountability is the control and responsibility of the leader to the assignor or parallel or horizontal parties. The indicator of fiscal accountability is the annual village administration accountability report document to the Regent or Mayor. Second is social accountability. This is the control and responsibility of the leader to certain community groups or interests. Indicators of social accountability can be in the form of rules and delivery of procedural information to the public, such as the availability of written documents and public information. The Last is bureaucratic accountability. This is the control and responsibility of the leader to the elements of the community, for example, the preparation of financial documents every certain period.

The transparency in the bureaucratic mechanism is very essentials in the way of the governance process. Along with the authority of autonomy to local governments, however, this has not been balanced with accountability (Putra, 2011). By decentralizing power to local government, local entities will have greater knowledge and abilities about services to rural communities, and it can develop policies that are appropriate to their specific needs, which in turn should encourage the participation and cooperation of all local stakeholders (Kelliher et al., 2014). According to (Jung et al., 2015), the participation of a myriad of stakeholders involved in the planning system of both national and local governance becomes more common and governance regards participation as a powerful driving force to effective planning and development. According to Hanida et al. (2017), a good relationship between stakeholders provides functions as partners and colleagues of local government work units at the regency level, including the village government. Stakeholder collaboration in cooperative development can be lesson learned (Soetriono et al., 2019), with implementing functions of member annual meeting, developing innovation, making economic partnerships, strengthening capital formation, facilitating members into the agribusiness chain, and improving the cluster of the production system.

According to Sharma \& Starik (2004), the role of stakeholders is an important element of organizational sustainability that helps organizational management guide understanding community issues and generates benefits for achieving prosperity. Jones \& Wick (1999) stated that stakeholders can 
contribute input, perspectives, and values or ethics in decision making, organizational governance in order to achieve organizational goals.

Savage et al. (2011) explained that stakeholders can focus on strategic matters to develop cooperation and strengthen social life. Carroli (1991), suggests the formation of stakeholder groups with specific interests or criteria according to the need in the organization. Stakeholder groups can influence the organization in carrying out activities, formulating objectives, and policy directions according to what was agreed upon. Mitchell et al. (1997) stated that stakeholders can develop ideas for managing organizations that are considered capable of providing the power of legitimacy and urgency for the public interest. Collaborative relationships are emphasized to promote mutual understanding in a group (Usadolo \& Caldwel, 2016) and stakeholders focus on various types of formal mechanisms rather than one type of formal mechanism for binding stakeholders (Ozdemir et al., 2019).

The village fund program was allocated first in 2015 by the central government approximately one billion rupiahs per village. The magnitude of the nominal budget is adjusted to several conditions such as population, area size, poverty rate, and geographical barrier level. Beside from the central government, the village also receives other budget sources such as village funds allocation (ADD) from district/city governments, manageable assets of crooked land, or dividends from village own businesses (BUMDes).

Pranggang village in Kediri regency is a village that presents development progress in various economic activities. The village also utilizes village funds to empower economic life in various activities. In 2017, the total condition of village finances was 2.295 billion rupiahs. The nominal budget came from village funds of 832.6 million, regent government 748.7 million, village fund allocation 497.0 million, provincial government financial assistance 99.25 million, profit sharing tax return 52.4 million, the surplus budget of end year 36.2 million and other revenue of 28.4 million.

With a such financial budget, the village of Pranggang is required to ensure a mechanism of accountability management to avoid the opportunities for fraud or inappropriate decision making. It is therefore necessary to strengthen various internal and external elements in the village stakeholders to monitor the performance of the village government in managing village finances. Collaboration between stakeholders and the village government is expected to provide learning and strengthen the management of accountable village governance. In the preliminary study, the role of collaborative stakeholders has not fully functioned to support the accountability of rural government administration.

This study is to provide identification of the collaboration of several stakeholders in village government affairs. This study aims to describe the collaborative stakeholders in the village of Pranggang in the implementation of village governance in terms of planning, implementation, administration, reporting, and village financial accountability.

\section{RESEARCH METHOD}

This research used a qualitative approach and method. This approach assumes that the research problem is still not identified or requires conformity about the problem being addressed. The research was carried out with field spot studies to explore research objects that focused on the role of stakeholder collaboration in managing village funds. The study also applied an interactive approach from Miles et al. (2014), where qualitative data analysis were carried out interactively and is carried out continuously until fulfillment, so that the data characteristics display a clear point and meet the validity requirements (Cropley, 2019).

The research location was in Pranggang village, Plosoklaten District, Kediri Regency. Data periods were collected in December 2019 - January 2020. The researchers used purposive sampling to select competent respondents who were able to answer and explain each finding. Interviews were conducted with village government officials, such as the village head, village secretary, village treasurer, head of development and planning affairs, head of community welfare affairs, and village community empowerment. Data collection was done through structured interviews, documentation, and observation with confirmation to produce valid findings.

The research variables were focused on village government accountability. The accountability variable was described in more detail in the implementation of village governance in terms of 
planning, implementation, administration, reporting, and village financial accountability.

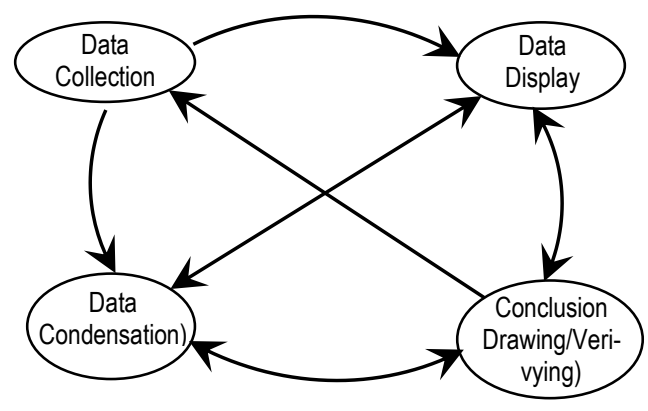

Figure 1. Data analysis of interactive model (Miles Huberman \& Saldana, 2014)

The analytical method used an interactive approach that has three steps. First is data condensation. It was worked by focusing, simplifying, abstracting, and transforming data based on all parts of written field notes, interview transcripts, documents and other empirical material.
Second is displaying data. It was to see the overall picture of research by trying to make instructions, tables, graphs, and others. The data were arranged in a relationship pattern so that it can be easily understood. Third is drawing or verifying conclusions. This final step was to draw conclusions or verify the research finding from qualitative research. It is expected to be new findings that have never existed. This finding can be in the form of an abstract object description to clear one after the study.

\section{RESULT AND DISCUSSION}

\section{Profile of Pranggang Village}

Pranggang village is in the administrative area of Plosoklaten district, Kediri regency, East Java province. The geographical location is at coordinates $-7.8479,112.1738$, and at $222 \mathrm{~m}$ above sea level. The annual rainfall reaches $1,902 \mathrm{~mm}$ with an average of 148 rainy days. The size area of Pranggang village reaches 10.56 square $\mathrm{km}$.

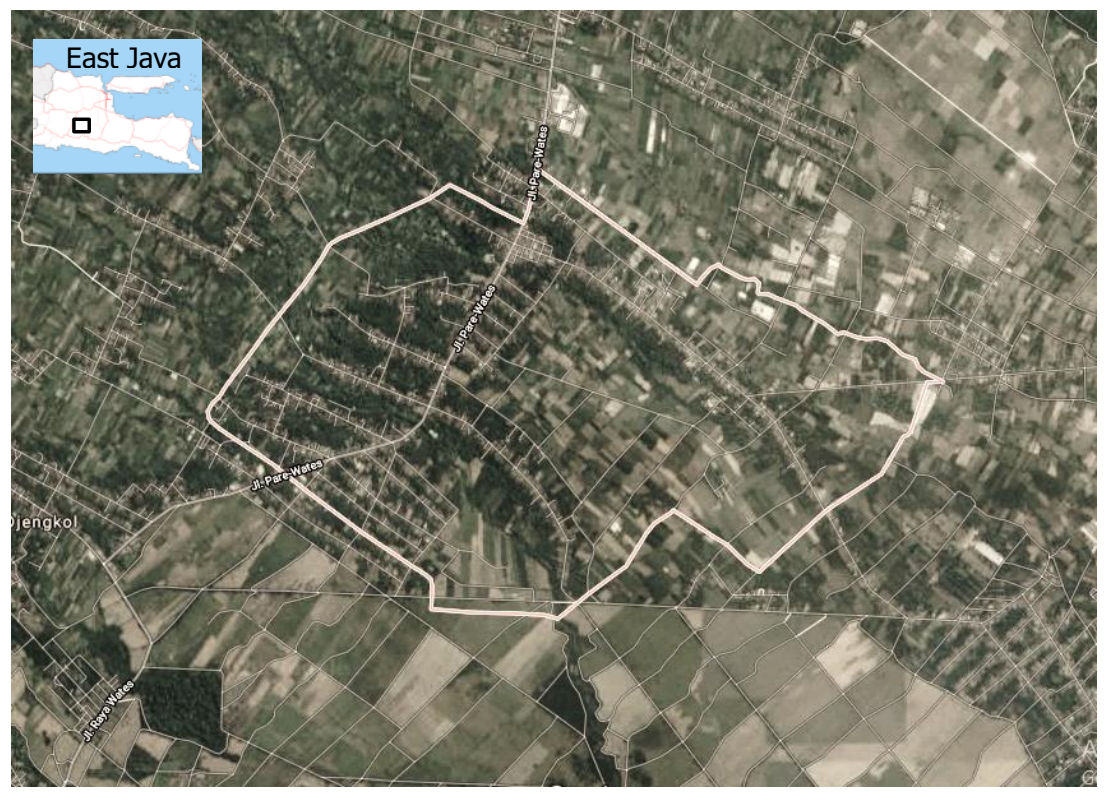

Figure 1. Map of Pranggang village (Source: google map)

The Pranggang village is located on the main road between Pare and Wates districts, or as alternative access from Surabaya to Blitar regency. Road infrastructure is in adequate condition to support socio-economic life and rural development. In the Plosklaten district, two villages are classified as kelurahan (a village that features urban attributes), namely Brenggolo village (capital of the district) and Pranggang village. This advantage can be understood because the Pranggang village has adequate urban facilities such as electricity, telecommunications, education, and the existence of a permanent market. 
The economic life of the village develops from agriculture activities, especially food crops. The village has 132 ha of rice fields and 761 ha of nonrice fields. The population reaches 8,804 people or 2,374 families. The population is 4,442 men and 4,362 women (Plosoklaten in Fiqures, 2019).

Pranggang village has abundant natural resource potential. The soil is characterized by high fertility, with alluvial soil parent material from the eruption of Kelud, which is located less than $50 \mathrm{~km}$ from Pranggang village. Abundant water resources to support rice farming and irrigation. Villagers seek freshwater fisheries and koi fish. Water source tourism is also beginning to be known by the surrounding areas and presents photo spots that are very interesting and instragamable.

The development progress of Pranggang village was also contributed by the village funding policy. In 2018, the village finance received village owned revenue (PAD) of 755 million, village fund allocation (ADD) of 497 million rupiahs, and fund sharing/grant of 162 million rupiahs. The magnitude of revenue of the Pranggang village is the highest compared to other villages in the Plosoklaten district (Table 1).

Table 1. Village Finance Revenue in Plosoklaten District, 2019

\begin{tabular}{|c|c|c|c|}
\hline Village & $\begin{array}{c}\text { Village } \\
\text { Owned } \\
\text { Revenue } \\
\text { (PAD) }\end{array}$ & $\begin{array}{l}\text { Village } \\
\text { Fund } \\
\text { Allocation } \\
\text { (ADD) }\end{array}$ & $\begin{array}{l}\text { Fund } \\
\text { Sharing } \\
\text { /grant }\end{array}$ \\
\hline & \multicolumn{3}{|c|}{............. million rupiahs ............ } \\
\hline Gondang & 518.9 & 363.1 & 709.8 \\
\hline Kayunan & 196.2 & 367.5 & 403.8 \\
\hline Panjer & 171.3 & 301.3 & 273.3 \\
\hline Jarak & 411.8 & 533.4 & 101.8 \\
\hline Sepawon & 50.0 & 465.0 & 167.0 \\
\hline Plosokidul & 458.0 & 378.3 & 661.0 \\
\hline Brenggolo & 752.9 & 417.6 & 199.4 \\
\hline Plosolor & 390.0 & 367.0 & 118.0 \\
\hline Wonorejo Trisulo & 215.0 & 430.0 & 253.0 \\
\hline Pranggang & 755.0 & 497.0 & 162.0 \\
\hline Punjul & 647.0 & 456.0 & 170.0 \\
\hline Klanderan & 574.0 & 353.0 & 66.0 \\
\hline Donganti & 264.0 & 287.2 & 355.0 \\
\hline Kawedusan & 997.2 & 398.5 & 552.0 \\
\hline Sumberagung & 478.0 & 498.0 & 60.0 \\
\hline Total & 6879.3 & 6112.9 & 4252.1 \\
\hline
\end{tabular}

\section{Stakeholders Collaboration}

Regional autonomy has opened opportunities for regional governments to develop regional policies appropriately. However, the implementation of the policy has not been maximized because local governments do not have adequate human resource capacity, particularly village government administrators. As a result, a lot of flaws or problems are reported in the implementation of development programs in the region. This is related to the lack of accountability of the village government which makes the implementation of regional autonomy ineffective and inefficient (Rozi et al., 2016).

The capacity of the village government is an important factor in achieving fiscal accountability. Several studies show the inability of the village government to carry out the planning, implementation and reporting of all existing regulations (Agiastuti \& Suputra, 2016). The role of quality of human resources in village development is important (Kulla et al., 2018; Wakerkwa, 2016). This does not include the collaboration role of stakeholders to provide input or improve development activities.

This research found pieces of evidence of a lack of collaboration among stakeholders in the implementation of village development. Collaboration between the village government with the district, provincial and other government agencies found points of weakness in the field of supervision and coordination. The village government wants to work responsibly in carrying out activities in the scope of its authority without making mistakes. Village officials try to carry out standard operating procedures for work, however, this often does not operate with reality on the spot. Therefore, the village government needs to obtain consideration or idea by involving various stakeholders involved in the implementation of village autonomy, especially in village financial accountability.

Mashari, the Head of Pranggang Village stated as follows:

"Our role as leaders is to mobilize the community so that they can actively participate in developing the rural area and building mutual empowerment. For example, the community is required to actively participate in program planning, or be involved in planned activities to be carried out by the village".

This statement shows that the Pranggang village government has tried to involve the community in the process of accessibility of rural development planning. This engagement process also leads the community to play an active role in the process of 
checks and balances and to raise public awareness in the development of the village for mutual benefit.

However, the involvement of the community and village government has not been sufficient to meet the need of rural development. The limited stakeholder involvement causes the accountability process to not run smoothly. External or wider stakeholder involvement should be immediately implemented to play an important role in assisting the village government in carrying out its duties and functions to become an independent village. Villages are required to have the ability and quality of human resources to manage their village resources properly. So far, the institutional regulations to meet the need of human resources and skilled workers in the village have not been fully conducted by the government. Stakeholders can collaborate to help the need of the village government, for example in technical guidance to improve the quality of human resources. The village government can involve the role of extension workers to broaden development insights, coach group strengthening training, or utilize information technology for rural development (Sabir et al., 2018) or increase entrepreneurial capacity in farm management (Umar et al., 2020).

In general, collaborative shareholders in Pranggang village have not been optimally utilized for supporting village fund management. According to (Overseas Development Administration, 1995), there are three categories of stakeholders. First is the existence of primary stakeholders. It is participation and functions carried out by the program manager and parties that are affected by program activities. In the village of Pranggang, they are the village government officials, the activity management team (TPK), and the community. Second is the existence of supporting stakeholders. They are universities, private sector, NGOs, or other government institutions. Their role does not yet fully function in supporting the management of village funds in Pranggang village. Third is key stakeholders. They are the ones who have the authority in regulation, legislation, or supervisory. This role is carried out by the village consultative body or community meeting forum.

\section{Government Accountability}

The implementation of regional autonomy is expected to increase the efficiency, effectiveness, and accountability of the public sector in Indonesia
(Christia \& Ispriyarso, 2019). With autonomy, provincial or regent regions are required to look for alternative sources of development funding without reducing essential of continued assistance and revenue sharing from the central government. Region government continues to drive development in various sectors using public funds following the priorities and aspirations of the community.

Local governments need to pay attention to efficiency in the mechanism of development implementation. Efficiency is the ratio of costs incurred to financial revenues in village government development activities (Pangkey \& Pinatik, 2015). The efficiency is commonly used to measure a certain income economically. The level of efficiency will be achieved if costs can be reduced and at the same time it produces increased revenue realization. A measure of efficiency can help to optimize the combination of input use or to produce a certain level of output at a lower cost. In other words, efficiency is the ability to produce as much output as possible from a given number of inputs.

Local governments carry out their functions effectively when supported in making decisions regarding budget expenditures in the public sector. Supports to the local governments are in the form of adequate financial resources from various sources such as local revenue (PAD), tax and non-tax revenue sharing, loans, and subsidies/assistance from the central government (Ferry et al., 2015; Hastuti, 2017). Meanwhile, to create an effective government, the government accountability should be established, including the village government. Villages must be prepared so that they can implement accountability in managing village financial budgets, including planning, implementation, and reporting (Fajri, 2015; Gayatri et al., 2017; Nafidah \& Anisa, 2017; Riskasari, 2016).

Regulation of Home Affairs Ministry Number 113 of 2014 states that financial management by local governments must meet the following five step, as follows:

Planning. Planning is expected to meet the need and aspirations of the rural community. All activities funded by Pranggang village funds are programs to meet the need of the rural community as a priority for village development. The village development program uses funds effectively and efficiently as determined by the regent government. This was revealed by Tony as apparatus of Pranggang Village: 
"The planning process starts at the musyawarah dusun (hamlet meeting), to formulate what priority programs to be proposed. When the program has agreed by the hamlet community, the village head will propose it at the Musrenbangdes (village development planning consultation). Next, all stakeholders such as the village officials, the Village Consultative Body, community, and religious leaders will provide consideration, correction, or notes to all programs proposed from the village. The decision then made, perhaps programs from hamlet $A$ or $B$, then will be agreed to execute".

Besides, Sumiati as one of the villagers of Pranggang village stated:

"We are always invited by the village government in planning every program that will be carried out in the village. Thus, the people know any programs of the rural government will carry out. And that is by mutually agreed upon. We, as the community, give advice and submit what is needed for the village. ".

This statement shows that the village government of Pranggang at the planning step conducted the principle of community involvement and transparency. The principle of transparency is held in high esteem by the managers of the village fund program in Pranggang village. This mechanism is expected to receive feedback/responses from the community in improving development performance.

Implementation. The management of the village fund always reports the progress of the implementation of activities timely to the village officials, especially regarding physical activities and absorption of funds. Mashari as Head of Pranggang Village revealed that:

"The implementation of the village funds operates under the instructions from the village treasurer to the activity management team (TPK), following the agreement of the village officials consultation prior to project implemented. Previously, the proposal had been prepared by the Village Financial Management Technical Implementation (PTPKD). The proposal contains details of the activity need budget as submitted by TPK to the village government. The village treasurer then carries out instructions based on the village officials' consultation and $R A P^{\prime}$.

This was also revealed by Endayanti as treasurer of Pranggang Village:

"All village funds are disbursed from the Village revenue and expenditure budget (the budget has been approved by the local government). The overall program of activities is funded by the village budget. Budget users then attach supporting data and proposal if available, such as notes, receipts, and other verification in the final report".

Pranggang village has conducted the principle of accountability in implementing the utilization of village funds. This is done by adopting a monthly reporting system at each step of the activity. Thus, it can be seen how the responsibilities of the village fund manager have fulfilled the provisions in the report phase of the implementation of the village fund activities and the final activity report. The accountability for the implementation of the village fund program to higher levels of government is done through a periodic reporting system. The village fund implementation report consists of a preliminary report, a report on each phase of activities, a monthly report, and a final report prepared in activities compiled comprehensively.

Administration. This step is done by keeping records of expenditures and receipts regarding village fund activities. Moreover, the activity implementation team (TPK) produces an accountability report in the form of a bookkeeping report that will be submitted to the village treasurer.

Mashari as the Head of Pranggang Village said that:

"The village treasurer has records and reports of bookkeeping of the expenditure and revenue of village funds. Then, the Activity Management Team (TPK) has an accountability report on financial activities. They reported to the head and secretary of the village. We will make improvements if necessary, and submit the report to the district government".

This was justified by Endayanti as treasurer of Pranggang village. She revealed the way in conducting financial administration reports. It has been arranged starting from the revenue, the expenditure to allocation. Financial administration data are compiled in detail and ensured that there are no administrative mistakes. The financial administration report is prepared based on the amount of expenditure and revenue. The village government of Pranggang strives to comply with detailed provisions of government regulations as well as to facilitate the implementation of development activities

Reporting. Reporting on the financial administration process in Pranggang Village follows the technical guidelines of the existing rules and 
regulations. The activity implementation team (TPK) began to make a report based on the bookkeeping of village revenue and expenditure, which was then discussed in a joint meeting of all Pranggang village government officials. After obtaining the approval of the village government, the report is then submitted to the Kediri district government. Mashari as the Village Head explained as follows:

"The financial reporting process by the activity management team (TPK) is prepared according to the existing guidelines. The report contains the realization of what has been spent according to needs. I as avillage head also evaluate and clarify data and findings. Evaluation is also carried out during the meeting forum discussing village funds. We want to ensure that improvements are made and the report is done correctly. "

Financial Accountability. This step is the responsibility of the financial administration of village funds that are arranged properly. The report encloses all evidence of expenditure sourced from village funds. All stakeholders such as village officials, treasurers, and activity implementation teams participate in evaluating the management of village funds. The community also actively participates in providing input and correction so that the implementation of activities and reporting can be completed following the provisions.

Village funds are one of the main sources of income to drive village development. The use of funds should be accounted transparently to the community and regent government as an authorized institution in the village development. Besides, accountability to the community is carried out regularly every three months through an evaluation meeting for the implementation of village funds, which is facilitated by the village head. The following are the results of an interview with Mashari as the head of Pranggang Village, who stated:

"Every three months, evaluation of the implementation of village funds is carried out by inviting community leaders, community empowerment agencies (LPM), and village consultative bodies (BPD). The evaluation is carried out to realize transparency in the management of village funds. This effort is expected to contribute input and advice to carry out responsible fund management. "

The management of financial administration is carried out in Pranggang village. This can be said to be following the principle of accountability, as the result of an interview with Endayanti as the treasurer of the village as follows:

"The village head and the village treasurer withdrew the village funds from the bank, and then give them to the treasurer of the activity management team (TPK). The TPK treasurer then reallocate the budget to the village treasurer to support village government activities."

The statement shows that the accountability of the implementation of village funds in Pranggang Village has carried out the principle of accountability. Village fund management has also implemented accountability in financial administration correctly. That is all expenses originating from village funds should be accompanied by evidence. The evaluation of the implementation of the village fund management program also involves the community to actively participate in providing input and correction through reciprocity between village officials, treasurers, and the management activity implementation team.

The accountability is a process carried out to account for the management of resources and the implementation of policies entrusted to the reporting entity in achieving the objectives that have been set regularly. Public accountability is a principle that guarantees that every activity carried out by the village government can be openly accounted for all levels of society (Nieto et al., 2015). Thus, accountability is a manifestation of the obligation to be responsible for managing and controlling resources and implementing budget policies to achieve the objectives of the village government. The principle of accountability determines that every activity and the result of village administration activities should be accountable to the village community and government officials following statutory provisions.

The Pranggang village government has also posted detailed APBDes budgeting on the activity information board and website. This is done to increase mutual trust among the village government and the community in the implementation of the village government, as well as increasing community participation in rural development.

Furthermore, the Pranggang village government has carried out procedural accountability of the village budget and village funds to the community based on Home Affairs Ministerial Regulation number 113 of 2014 in managing the village government 
finances. Furthermore, social accountability has been applied in various forms of effective interactions between the community and the village government. Social accountability initiatives need to involve state actors (village government) and the community, with a focus on the interface and partnership between them. Social accountability will find effective and significant results when citizens, media and bureaucrats have an incentive to act (Ackerman, 2005).

Malena et al. (2004) said that the media plays an important role in promoting social accountability. In many countries, independent media are the main force in informing and educating citizens, monitoring government performance, and exposing inappropriate policies. Local-level media (in particular, private and community radio) provide important tools that grass-root citizens can voice their opinions and discuss public issues. A common element of successful social accountability initiatives is the strategic use of traditional and modern media uses to raise awareness about public issues, disseminate findings, and create platforms for public debate.

On the other hand, vertical accountability also runs where the village government has reported responsibility report regularly to the regent/city government. Meanwhile, horizontal accountability is reported by the village head or budget user in the village consultation forum at the end of the year both verbally and administratively. According to Mitchell et al. (1997) and Nieto et al. (2015), stakeholders play a role in developing ideas for managing organizations from the highest to the lowest level that is considered capable of providing the power of legitimacy and urgency for the public interest. Furthermore, Imawan et al. (2019) stated that the village government must improve the administration system and increase the participation of village representative bodies to gain legitimacy. Improving the quality of human resources in the village requires stakeholder involvement and collaboration.

The capacity of civil society actors is another key factor of successful social accountability. The level of Civil Society Organizations (CSOs), the extent of their membership, technical skills, and advocacy can contribute more value to mobilizing and using the media effectively. Their legitimacy, representation, level of responsiveness, and accountability to members are at the core of the success of social accountability activities (Malena et al., 2004). Open collaboration has evolved as a new form of innovation created in the public sector. Government organizations use collaborative to create or contribute to public sector innovations with the help of external and internal problem solvers (Mergel, 2015).

The success of social accountability initiatives also depends on the capacity and effectiveness of the government. Government capacity can influence the success of social accountability initiatives. The government may also require capacity building investments, including the ability to produce records and accounts; the existence of conventional horizontal accountability mechanisms; the effective delegation of authority and resources; the will and capacity to build partnerships or coalitions. Social accountability will develop through a political or administrative culture that respects the notion of honesty, accountability, and equality in the public sector. This can be overcame through a computerized accounting system and increasing the intensity of village representatives' deliberations.

\section{CONCLUSION AND SUGGESTION}

The results of this study indicate collaborative stakeholders in Pranggang village and community participation in managing village funds. Stakeholders involved in collaboration with the Pranggang village government need to have a contribution through the availability of resources, organizational and institutional regulatory mechanisms. Efforts are needed to improve the quality of human resources so that the realization of village government accountability goes well by involving provincial, regent and district governments.

The communication among stakeholders needs to be built to create effective collaboration. The scope of collaborative stakeholders covers the range of coordination between the village, district, and regent governments or with other government institutions so that planning and management of village development are carried out appropriately.

Collaborative stakeholders play a positive role in bringing about village accountability in managing village funds. This role also enables increased community participation in evaluating program activities, and increasing efficiency and effectiveness in the accountability of the village financial 
management sector. Moreover, the Pranggang village government has carried out procedural accountability of village funds to the community based on Regulation of Home Affairs Ministerial number 113 of 2014.

\section{REFERENCES}

Ackerman, J. M. (2005). Social Accountability for the Public Sector: A Conceptual Discussion. Washington DC: World Bank. Retrieved from http://documents1.worldbank.org/curated/en/514 581468134386783/pdf/357330Ackerman.pdf

Agiastuti, I. A. P., \& Suputra, I. D. G. D. (2016). Faktor-faktor yang mempengaruhi pada voluntary auditor switching. E-Jurnal Akuntansi Universitas Udayana, 17(1), 56-83. Retrieved from https://ojs.unud.ac.id/index.php/Akuntansi/article /view/17608

Bovens, M., Schillemans, T., \& Hart, P. (2008). Does public accountability work? an assessment tool. Public Administration, 86(1), 225-242. https://doi.org/10.1111/j.14679299.2008.00716.x

Carroli, A. B. (1991). The pyramid of corporate social responsibility: toward the moral management of organizational stakeholders. Business Horizons, 34(4), 39-48. https://doi.org/10.1016/00076813(91)90005-G

Christia, A., \& Ispriyarso, B. (2019). Desentralisasi fiskal dan otonomi daerah di Indonesia. Law Reform, 15(1), 149-136. https://doi.org/10.14710/Ir.v15i1.23360

Cropley, A. (2019). Qualitative research methods: A practice-oriented introduction for students of psychology and education (2nd ed.). Latvia: Zinātne.

https://books.google.co.id/books?id=AOHktgAACA AJ

Drake, S., \& Dingler, R. (2001). The Practical Guide to Finance and Accounting. Prentice Hall. https://books.google.co.id/books?id=Ie8rAQAAIA A]

Fajri, R. (2015). Akuntabilitas pemerintah desa pada pengelolaan alokasi dana desa (studi pada kantor desa Ketindan, kecamatan Lawang, kabupaten Malang). Jurnal Administrasi Publik (JAP), 3(7), 1099-1104. Retrieved from http://administrasipublik.studentjournal.ub.ac.id/i ndex.php/jap/article/view/920

Ferry, L., Eckersley, P., \& Zakaria, Z. (2015). Accountability and transparency in english local government: moving from "matching parts" to "awkward couple"? Financial Accountability and Management, 31(3), 345-361. https://doi.org/10.1111/faam.12060

Gayatri, Latrini, M. Y., \& Widhiyani, N. L. S. (2017). Transparansi dan akuntabilitas pengelolaan keuangan dana desa untuk mendorong kemandirian masyarakat pedesaan. Jurnal Ekonomi Kuantitatif Terapan, 10(2), 175-182. https://doi.org/10.24843/JEKT.2017.v10.i02.p07.

Hanida, R., Irawan, B., \& Rahayu, W. (2017). Collaboration of stakeholders in formation and development Nagari-Owned enterprise. \& Governance Review, 1(3), 2580-4820. Retrieved from https://journal.iapa.or.id/pgr/article/view/58

Hastuti, H. W. (2017). Pengaruh gaya kepemimpinan dan birokrasi terhadap akuntabilitas kinerja instansi pemerintah dengan good government governance sebagai variabel moderasi (studi pada SKPD kabupaten Bojonegoro). Retrieved from http://repository.unair.ac.id/65784/

Imawan, A., Irianto, G., \& Prihatiningtias, Y. W. (2019). Peran akuntabilitas pemerintah desa dalam membangun kepercayaan publik. Jurnal Akuntansi Multiparadigma, 10(1), 156-175. https://doi.org/10.18202/jamal.2019.04.10009

Jones, T. M., \& Wick, A. C. (1999). Convergent stakeholder theory. Academy of Manage Rewiew, 24(2), 206-221. https://doi.org/10.5465/amr.1999.1893929

Jung, T., Lee, J., Yap, M., \& Ineson, E. (2015). The role of stakeholder collaboration in culture-led urban regeneration: a case study of the Gwangju project, Korea. Cities, 44, 29-39. https://doi.org/10.1016/j.cities.2014.12.003

Kelliher, F., Aylward, E., \& Lynch, P. (2014). Exploring rural enterprise: the impact of regional stakeholder engagement on collaborative rural networks. Contemporary Issues in Entrepreneurship Research, 4, 35-57. https://doi.org/10.1108/S2040724620140000004002

Kulla, T., Rumapea, P., \& Tampongangoy, D. (2018). Kualitas sumber daya manusia dalam meningkatkan pembangunan desa tinggilbet distrilk beoga kabupaten Puncak provinsi Papua. Jurnal Administrasi Publik, 4(58), 1-11. Retrieved from https://ejournal.unsrat.ac.id/index.php/JAP/article /view/19784

Malena, C., Forster, R., \& Singh, J. (2004). The Role of Civil Society in Holding Government 
Accountable: A Perspective from The World Bank on The Concept and Emerging Practice. Social Development, $1-76$. http://www.istr.org/resource/resmgr/working_pa pers_toronto/malena.carmen.pdf

Mergel, I. (2015). Open collaboration in the public sector: the case of social coding on GitHub. Government Information Quarterly, 32(4), 464472. https://doi.org/10.1016/j.giq.2015.09.004

Miles, M. B., Huberman, A. M., \& Saldana, J. (2014). Qualitative Data Analysis. SAGE Publications. https://books.google.co.id/books?id=3CNrUbTu6 CsC

Mitchell, R. K., Agle, B. R., \& Wood, D. J. (1997) Toward a Theory of stakeholder identification and salience: defining the principle of who and what really counts. The Academy of Management Review, 22(4), 853-886. Retrieved from https://www.jstor.org/stable/259247

Nafidah, L. N., \& Anisa, N. (2017). Akuntabilitas pengelolaan keuangan desa di Kabupaten Jombang. Akuntabilitas: Jurnal Ilmu Akuntansi, 10(2), 237-288. https://doi.org/10.15408/akt.v10i2.5936

Nieto, A. P., Soriano, C., Llorente, M., Palomo, I., Montes, C., \& López, B. (2015). Collaborative mapping of ecosystem services: The role of stakeholders' profiles. Ecosystem Services, 13, 141-152.

https://doi.org/10.1016/j.ecoser.2014.11.006

Overseas Development Administration (ODA). (1995). A Guide to Social Analysis for Projects in Developing Countries. In HMSO. Scientific Research Publishing, Inc, https://books.google.co.id/books?id=4iyfNT24CwC

Ozdemir, S., Kandemir, D., Eng, Y., \& Gupta, S. (2019). Vertical stakeholder collaborations for firm innovativeness in new product development: the moderating roles of legal bonds and operational linkages. Journal of Business Research.

https://doi.org/10.1016/j.jbusres.2019.08.014

Pangkey, I., \& Pinatik, S. (2015). Analisis efektivitas dan efisiensi anggaran belanja pada dinas kebudayaan dan pariwisata provinsi Sulawesi Utara. Jurnal EMBA, 33, 33-43. https://doi.org/10.35794/emba.v3i4.10581

Plosoklaten in Figures. (2019). Kecamatan Plosoklaten Dalam Angka 2019. BPS of Kediri Regency. Retrieved from https://kedirikab.bps.go.id/publication/2019/09/2 6/581d30d8b9d9a2f313e94b43/kecamatanplosoklaten-dalam-angka-2019.html

Putra, D. Y. (2011). Peran sektor perikanan dalam perekonomian dan penyerapan tenaga kerja di Indonesia, analisis input output. Jurnal Maritime Economy, 3, 1-93. Retrieved from http://repository.unand.ac.id/16940/1/peran_sekt or_perikanan.pdf

Rahmaddhana, F. H., \& Sentanu, I. G. E. P. S. (2020). Akuntabilitas kinerja pemerintah daerah: Sebuah kajian analisis pada dinas perumahan dan kawasan permukiman Kota Malang. Prosiding Simposium Nasional "Tantangan Penyelenggaraan Pemerintahan Di Era Revolusi Indusri 4.O", 14021427.

Riskasari. (2016). Akuntabilitas pengelolaan alokasi dana desa di Desa Bongki Lengkese Kecamatan Sinjai Timur Kabupaten Sinjai. Jurnal Office, 2(2), 125-132.

Rizkita, S. (2016). Akuntabilitas pemerintah desa. Kedesa.Id. Retrieved from http://kedesa.id/id_ID/akuntabilitas-pemerintahdesa/

Rozi, F., Novianti, T., \& Aziz, A. (2016). Sistem informasi akuntabilitas kinerja instansi pemerintah pada biro organisasi pemerintah provinsi Jawa Timur. Retrieved from http://repository.umsurabaya.ac.id/1237/

Sabir, S., Sugiyanto, S., Sukesi, K., \& Yuliati, Y. (2018). The performance of agricultural extension workers in utilizing cyber extension in Malang Raya Region. Journal of Socioeconomics and Development, 1(2), 113-120. https://doi.org/10.31328/jsed.v1i2.772

Savage, G. T., Bunn, M. D., Gray, B., Xiao, Q., Wang, S., Wilson, E. J., \& Williams, E. S. (2011). Stakeholder Collaboration: Implications for Stakeholder Theory and Practice. Journal of Business Ethics, January, 9.

Scott, W. (2003). Financial accounting theory (Third). Pretice Hall. https://books.google.co.id/books?id=76epLQAAC AAJ

Setiawan, R., Samin, R., \& Mahadiansar. (2018). Dampak desentralisasi terhadap kapabilitas kepala daerah; studi kasus gubernur riau periode tahun 2008-2013. Jurnal Ilmu Administrasi Negara (JUAN), 6(2), 15-24. Retrieved from https://ojs.umrah.ac.id/index.php/juan/article/vie w/709

Sharma, S., \& Starik, M. (2004). Stakeholders, The Environment, and Society; New Perspectives in 
Research on Corporate Sustainability. Edward Elgar Publishing. https://books.google.co.id/books?id=3VzGJEYiI5 QC

Sisto, R., Lopolito, A., \& Vliet, M. (2018). Stakeholder participation in planning rural development strategies: using backcasting to support local action groups in complying with CLLD requirements. Land Use Policy, 70, 442-450. https://doi.org/10.1016/j.landusepol.2017.11.022

Soetriono, S., Soejono, D., Zahrosa, D., Maharani, A., \& Hanafie, R. (2019). Strategy and policy for strengthening the agricultural cooperative business in East Java, Indonesia. Journal of Socioeconomics and Development, 2(1), 12-22. https://doi.org/10.31328/jsed.v2i1.886

Solikhah, B., \& Yulianto, A. (2018). Mewujudkan akuntabilitas pengelolaan dana desa dengan aplikasi sistem keuangan desa (SISKEUDES). Seminar Nasional Kolaborasi Pengabdian Pada
Masyarakat, 1 ,

434-438. https://proceeding.unnes.ac.id/index.php/snkppm

Umar, M., Nugroho, I., Darmadji, D., \& Suwarta, S. (2020). The study of entrepreneurship and innovation adoption by farmer in improving lowland rice farming. Journal of Socioeconomics and Development, 3(1), 16-28. https://doi.org/10.31328/jsed.v3i1.1290

Usadolo, S. E., \& Caldwel, M. (2016). A Stakeholder approach to community participation in a rural development project. SAGE Open, 6(1). https://doi.org/10.1177/2158244016638132

Wakerkwa, O. (2016). Peranan sumber daya manusia dalam meningkatkan pembangunan masyarakat di Desa Umbanume Kecamatan Pirime Kabupaten Lanny Jaya. Jurnal Holistik, 17(1), 1-22. Retrieved from https://ejournal.unsrat.ac.id/index.php/holistik/art icle/download/12088/11670 